\title{
Biodiversity of nekton in Batangtoru River and its tributaries in North Sumatra, Indonesia
}

\author{
DESRITA $^{1, \boldsymbol{v}}$, AHMAD MUHTADI ${ }^{1}$, RUSDI LEIDONALD $^{1}$, RINA D'RITA SIBAGARIANG $^{2}$, NURFADILLAH ${ }^{3}$ \\ ${ }^{1}$ Department of Aquatic Resources Management, Faculty of Agriculture, Universitas Sumatera Utara. Jl. Prof A. Sofyan No. 3, Medan 20155, North \\ Sumatra, Indonesia. Tel./fax.: +62-61-8213236, `email: desrita@usu.ac.id \\ ${ }^{2}$ Department of Aquatic Resources Management, Faculty of Fisheries and Marine Science, Universitas Riau. Jl. HR Soebrantas Km 12.5, Kampus \\ Binawidya, Pekanbaru 28293, Riau, Indonesia \\ ${ }^{3}$ Faculty of Marine Science and Fisheries, Universitas Syiah Kuala. J1. Putroe Phang, Darussalam, Syiah Kuala, Banda Aceh 23111, Aceh, Indonesia
}

Manuscript received: 26 February 2020. Revision accepted: 3 May 2020.

\begin{abstract}
Desrita, Muhtadi A, Leidonald R, Sibagaring RD, Nurfadillah 2020. Biodiversity of nekton in Batangtoru River and its tributaries in North Sumatra, Indonesia. Biodiversitas 21: 2344-2352. Batangtoru River which flows from the Tapanuli highlands (i.e., Sipirok, Tarutung, Siborong-borong, and Silangit) to the southwestern Indian Ocean is an important habitat for aquatic organisms in the western region of North Sumatra. This research was done to provide basic data on biodiversity of aquatic organisms in Indonesia, especially North Sumatra. The study was conducted in July-August 2019. Nekton was captured using backpack electrofishing units (12 volts and 9 Amperes), traps, nets, and bamboo trap. This study found 68 nekton species, consisting of fish (57 species), crab (3), shrimp (6), lobster (1), and 1 freshwater turtle (1). In general, nekton found in the Batangtoru River and its tributaries are native and economically valuable fish (Tor and eel), including the newly discovered species, which was, Hemibagrus caveatus. Invasive fish found consisted of 6 species, i.e., Cyprinus carpio, Oreochromis mossambicus, Oreochromis niloticus, Xiphophorus helleri, Hypostomus plecostomus, and Trichogaster pectoralis. The only invasive crustacean found was freshwater crayfish (Cherax quadricarinatus).
\end{abstract}

Keywords: Baung suat, freshwater fish, Tapanuli

\section{INTRODUCTION}

Batangtoru watershed has an area of $303,181.82$ ha (North Sumatra Province Regional Spatial Plan 2017-2037) with the length of the main river of $174 \mathrm{~km}$. The average water flow of Batangtoru River is $106 \mathrm{~m}^{3} \mathrm{~s}^{-1}$, with the minimum flow of $41.90 \mathrm{~m}^{3} \mathrm{~s}^{-1}$ and the maximum flow of $484 \mathrm{~m}^{3} \mathrm{~s}^{-1}$ (PT. North Sumatra Hydro Energy 2016). Thus, Batangtoru watershed is the main ecosystem for conservation of water preservation in North Tapanuli and South Tapanuli. This ecosystem is also an important habitat for the flora and fauna diversity in Tapanuli region, including aquatic organisms such as nekton (fish, shrimps, and crabs). Because the river flowing from Tapanuli highlands (such as Sipirok, Tarutung, Siborong-borong, and Silangit) to the southwestern Indian Ocean is an ideal habitat for aquatic organisms. As stated by Odum and Barrett (2009) and Gordon et al. (2004), rivers and their tributaries are highly suitable habitats for various types of aquatic organisms including nekton.

Nekton is organisms that can swim and move actively, such as fish, shrimps, amphibians, and large aquatic insects (Welch 1954; Odum and Barrett 2009). Although shrimps and crabs tend to live at the bottom of the water, because of their ability to swim freely and against the flow, they can be categorized as nekton (Welch 1954; Odum and Barrett 2009). Kottelat et al. (1993) recorded that at least there are 1,300 freshwater fish species in Indonesia, most of which are found in the river waters. Wowor et al. (2019) found 4 species of freshwater crabs and 23 species of native crustaceans in the Cisadane watershed. Meanwhile, Suryono (2006) found 10 species of crabs in an estuary.

Therefore, since Batangtoru River that flows across Tapanuli region is wide and long, it is necessary to conduct a study on the condition of nekton habitat and biodiversity in Batangtoru River and its tributaries. This can be used as inventory data for various uses and management of Batangtoru watershed. However, the studies related to the biodiversity of nekton and macroinvertebrate in the Batangtoru River are still rarely done. So far the studies related to aquatic biodiversity have been conducted only by the Amdal Team from PT. North Sumatra Hydro Energy (2016). The team found only 10 species of fish and 9 species of macroinvertebrates in Batangtoru River, which are considered low as Batangtoru River is large and long. Small sampling location (not spread evenly) and one-time sampling might have caused the low diversity found in that study. As a comparison, studies in Wampu watershed by Muhtadi et al. (2017) and Desrita et al. (2018) found at least 26 species of fish, 3 freshwater shrimps, and 1 freshwater crab. The objective of this study was to provide basic data on diversity of aquatic organisms in North Sumatra, Indonesia.

\section{MATERIALS AND METHODS}

\section{Study area}

The sampling of nekton was done in Batangtoru River and its tributaries (Figure 1) which cover North Tapanuli, 
South Tapanuli, and Mandailing Natal of North Sumatra Province, Indonesia. There were 34 observation stations, consisting of 4 points in downstream, 8 points in middle stream, 5 stations in upstream, 9 stations in tributaries, and 6 stations in sub tributaries. The sampling was conducted in July-August 2019.

\section{Procedures}

Nekton was captured by-using backpack electrofishing units with 12 volts and 9 Amperes. This tool is very effective for shallow waters such as rivers and tributaries. Electrofishing operations for each location were carried out along the two tributaries. The electrofishing operator moved to the opposite direction of the river's current (moving upstream), and collected the fainting fish by-using hand nets and put them in a plastic bag or bucket. In addition, nekton was also captured using traps and nets.
Nekton samples were then photographed and preserved in $10 \%$ formalin solution, labelled with local name of the fish, location/station, date of collection, collector's name, and other information required. The identification was conducted in the Integrated Resource Management Laboratory, Faculty of Agriculture, Universitas Sumatera Utara, Medan, Indonesia based on Kottelat et al. (1993), and fishbase.org, Wowor et al. (2004) and Wowor (2010) as references.

\section{Data analysis}

The diversity of nekton communities in waters was determined using several indexes, i.e., the Shannon-Wiener diversity index $\left(\mathrm{H}^{\prime}\right)$, evenness index $(\mathrm{E})$, and dominance index (D) (Krebs 1989). Diversity index (H') was used to get a mathematical representation of organism populations. It can simplify the information analysis of the individual of each species in a community (Odum and Barrett 2009).

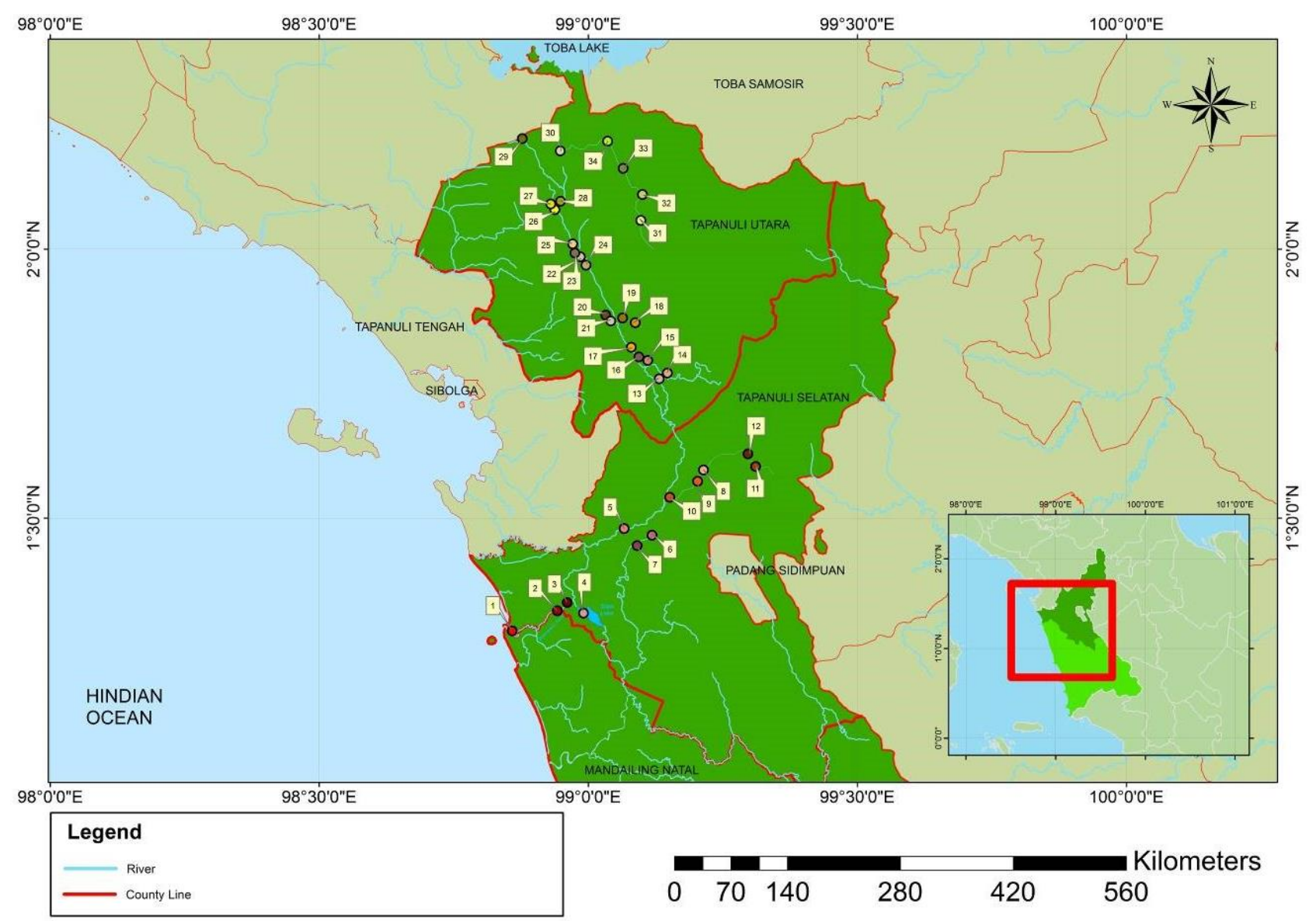

Figure 1. Location of the Batangtoru Watershed. station $1\left(1^{\circ} 17^{\prime} 21.45^{\prime \prime} \mathrm{N}, 98^{\circ} 50^{\prime} 33.81 " \mathrm{E}\right)$, station $2\left(1^{\circ} 17^{\prime} 26.07^{\prime \prime} \mathrm{N}, 98^{\circ} 54^{\prime} 34.85^{\prime \prime} \mathrm{E}\right)$, station $3\left(1^{\circ} 19^{\prime} 43.58^{\prime \prime} \mathrm{N}, 98^{\circ} 57^{\prime} 4.20^{\prime \prime} \mathrm{E}\right)$, station $4\left(1^{\circ} 19^{\prime} 16.51^{\prime \prime N}, 98^{\circ} 59^{\prime} 42.96 " \mathrm{E}\right)$, station $5\left(1^{\circ} 28^{\prime} 43.46^{\prime \prime} \mathrm{N}, 99^{\circ} 4^{\prime} 5.31^{\prime \prime E}\right)$, station 6

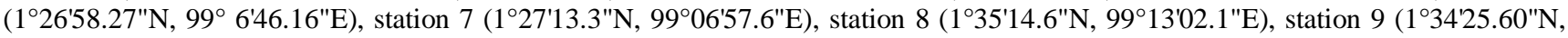
$\left.99^{\circ} 12^{\prime} 29.17^{\prime \prime E}\right)$, station $10\left(1^{\circ} 32^{\prime} 15.06^{\prime \prime N}, 99^{\circ} 9^{\prime} 42.17^{\prime \prime} \mathrm{E}\right)$, station $11\left(1^{\circ} 36^{\prime} 12.9^{\prime \prime} \mathrm{N}, 99^{\circ} 18^{\prime} 18.8^{\prime} \mathrm{E}\right)$, station $12\left(1^{\circ} 36^{\prime} 05.17^{\prime \prime} \mathrm{N}\right.$, $\left.99^{\circ} 18^{\prime} 23.60 " \mathrm{E}\right)$, station $13\left(1^{\circ} 45^{\prime} 6.10^{\prime \prime} \mathrm{N}, 99^{\circ} 8^{\prime} 12.71^{\prime \prime E}\right)$, station $14\left(1^{\circ} 45^{\prime} 24.98^{\prime \prime} \mathrm{N}, 99^{\circ} 8^{\prime} 17.88^{\prime \prime} \mathrm{E}\right)$, station $15\left(1^{\circ} 47^{\prime} 42.43^{\prime \prime} \mathrm{N}, 99^{\circ}\right.$ $\left.6^{\prime} 46.90^{\prime \prime E}\right)$, station $16\left(1^{\circ} 47^{\prime} 46.13^{\prime \prime} \mathrm{N}, 99^{\circ} 6^{\prime} 39.21^{\prime \prime E}\right)$, station 17 ( $\left.1^{\circ} 48^{\prime} 11.05^{\prime \prime} \mathrm{N}, 99^{\circ} 5^{\prime} 31.96^{\prime \prime} \mathrm{E}\right)$, station $18\left(1^{\circ} 51^{\prime} 8.72^{\prime \prime} \mathrm{N}, 99^{\circ} 5^{\prime} 0.51^{\prime \prime} \mathrm{E}\right)$, station $19\left(1^{\circ} 52^{\prime} 15.13^{\prime \prime} \mathrm{N}, 99^{\circ} 33^{\prime} 39.01^{\prime \prime E}\right)$, station $20\left(1^{\circ} 51^{\prime} 52.21^{\prime \prime N}, 99^{\circ} 2^{\prime} 48.77^{\prime \prime E}\right)$, station $21^{\circ}\left(1^{\circ} 51^{\prime} 55.61^{\prime \prime N}, 99^{\circ} 2^{\prime} 53.02^{\prime \prime} \mathrm{E}\right)$, station 22 $\left(1^{\circ} 59^{\prime} 4.73^{\prime \prime} \mathrm{N}, 98^{\circ} 59^{\prime} 9.58^{\prime \prime} \mathrm{E}\right)$, station $23\left(1^{\circ} 59^{\prime} 4.09^{\prime \prime} \mathrm{N}, 98^{\circ} 59^{\prime} 4.67^{\prime \prime} \mathrm{E}\right)$, station 24 ( $\left.^{\circ} 58^{\prime} 46.53^{\prime \prime} \mathrm{N}, 98^{\circ} 59^{\prime} 15.38^{\prime \prime} \mathrm{E}\right)$, station 25 $\left(1^{\circ} 59^{\prime} 4.49^{\prime \prime} \mathrm{N}, 98^{\circ} 59^{\prime} 2.76 " \mathrm{E}\right)$, station $26\left(2^{\circ} 4^{\prime} 15.45^{\prime \prime} \mathrm{N}, 98^{\circ} 56^{\prime} 21.35^{\prime \prime E}\right)$, station $27\left(2^{\circ} 4^{\prime} 37.69^{\prime \prime} \mathrm{N}, 98^{\circ} 56^{\prime} 9.79^{\prime \prime} \mathrm{E}\right)$, station $28\left(2^{\circ}\right.$

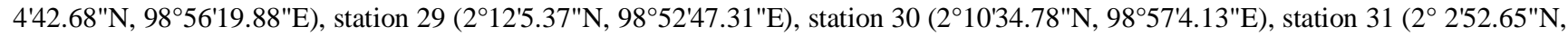
$\left.99^{\circ} 6^{\prime} 0.05^{\prime \prime E}\right)$, station $32\left(2^{\circ} 5^{\prime} 56.25^{\prime \prime} \mathrm{N}, 99^{\circ} 6^{\prime} 10.91 " \mathrm{E}\right)$, station $33\left(2^{\circ} 8^{\prime} 53.97 " \mathrm{~N}, 99^{\circ} 4^{\prime} 6.08^{\prime \prime} \mathrm{E}\right)$, station $34\left(2^{\circ} 11^{\prime} 50.58^{\prime \prime} \mathrm{N} 99^{\circ}\right.$ $\left.2^{\prime} 11.13 " \mathrm{E}\right)$; and the detected sites 
Nekton diversity was calculated by using the diversity index of Shannon and Wiener (1963) in Odum and Barrett (2009) with this formula:

$$
\mathrm{H}^{\prime}=-\left(\sum \text { pi ln pi }\right)
$$

Whereas,

H' : The diversity index,

ni : The number of individuals in the $i$ th species,

$\mathrm{N}$ : Total number of individuals,

$\mathrm{Pi}$ : The ratio of individuals of species $i$ to all individuals of all species. $=\mathrm{ni} / \mathrm{N}$.

The evenness index (E) was used to measure the individual evenness among species, calculated using the following equation:

$\mathrm{E}=\mathrm{H}^{\prime} / \mathrm{H}^{\top} \max$

Whereas,

E : The evenness index,

$\mathrm{H}^{\prime} \quad$ : The diversity of species,

$\mathrm{H}^{\prime} \max$ : The maximum of diversity index $(\mathrm{InS})$,

S : Total number of species.

Dominance index describes the species composition in the community. Dominance index was calculated according to Simpson's index in Krebs (1989), using the following equation:

$$
\begin{aligned}
& \mathrm{D}=\sum\left(\frac{n i}{N}\right)^{2} \\
& \text { Whereas, } \\
& \mathrm{C}: \text { dominance index, } \\
& \text { ni : The number of individuals in the } i \text { th species, } \\
& \mathrm{N}: \text { The total number of individuals in community. }
\end{aligned}
$$

\section{RESULTS AND DISCUSSION}

\section{Abundance and species composition of nekton}

This study found 68 nekton species, consisting of 57 species of fish, 3 species of crab, 6 species of shrimp, and 1 species of lobster, and 1 species of freshwater turtle (Table 1). The nekton belonged to 28 families, consisting of 23 families of fish, 4 families of crustacean, and 1 family of reptile. The fish from the Family Cyprinidae were more frequently found than those from other families. In total, there were 19 species of Cyprinidae found in the Batangtoru River and its tributaries. Some studies found more species than in the Batangtoru River and its tributaries, such as; Muhtadi et al. (2017) and Desrita et al. (2018) found 50 species of nekton (42 fishes) in the Wampu watershed; Dekar et al. (2018) found 44 fish species in Aceh River, and Irhami et al. (2018) found 32 species in Meureubo River, West Aceh.

Cyprinidae is a family of freshwater fish that has the most species in the world, except in Australia, Madagascar, New Zealand, and South America (Kottelat et al. 1993). Furthermore, Zakaria-Ismail (1994) stated that Cyprinidae is the largest freshwater fish group in the Southeast Asian region including freshwater in the Sumatra island (Margasasmita 2002). Nguyen and De Silva (2006) confirmed that freshwater fish species in Asian region are dominated by Cyprinidae fish groups (approximately 1000 species), followed by loaches (Families Balitoridae and Cobitidae) (approximately 400 species), Gobiidae (300 species), Bagridae (100 species), and Osphronemidae (85 species). Shrimp group of the Family Palaemonidae is the second most found species in the Batangtoru watershed, and at least 6 species were found in the research site. Fish from the Family Bagridae became the third-largest after Cyprinidae, with 5 species found.

Studies on several rivers in Sumatra Island have shown similar results, for example in the waters of the Bukit Tigapuluh Siberida area the Family Cyprinidae was found as the main inhabitants with the largest population, followed by catfish groups (Bagridae, Clariidae, Pangasidae) (Siregar et al. 1993). In Enim River, South Sumatra, 28 species of 11 fish families were found, consisting of 14 species of Cyprinidae, 4 species of Cobitidae, and 2 species of Balitoridae (2 species) (Hamidah 2004). Muchlisin and Siti-Azizah (2009) reported that there were 114-711 species of fish, consisting of 69 genera, and 41 families found in Aceh waters. In Asahan River, North Sumatra, there were 14 species Cyprinidae, 3 species Balitoridae, 3 species of the families Clariidae, and Bagridae (Simanjuntak 2012a) and 16 species from 10 genera and 8 families in Sopokomil tributaries, Dairi, North Sumatra (Simanjuntak 2012b). Pranata et al. (2016) found 3 orders, 7 families of 13 genera and 16 species of fish in Sangkir River, Rokan Hulu Regency, Riau Province. Muhtadi et al. (2017) and Desrita et al. (2018) found 12 species and 3 species of Bagridae in the upstream waters of Batangtoru watershed with a total of 37 species of nekton species.

Mahseer, swamp barb, glass shrimp, and panchax minnow were found in every observation location, showing that the Batangtoru River is a suitable habitat for those species because it has low flow (suitable for swamp barb and glass shrimp), strong flow (suitable for mahseer), and rocky and sandy substrates. River waters that have a swift flow are mahseer's fish favorite habitats (Muhtadi et al. 2017; Desrita et al. 2018). Cencen, baung, crab, mountain catfish, incor, and small-size mahseer are commonly found in the river with moderate flow, while keperas, Guppy, and shrimp in habitat at low tide. The less commonly found fish (with restricted distribution) besides the brackish fish (station 1) were $R$. spilotaenia (point 30) and N. longipinnis (stations 18 and 30). A new species $H$. caveatus that was discovered in Alas river (Aceh) (Hee et al. 2001), was also found in the downstream Batangtoru River during this study.

In Batangtoru River and its tributaries, 6 species of freshwater shrimp of the Macrobrachium and 1 lobster were found. Macrobrachium is a freshwater crustacean. Most of the freshwater shrimps found in Indonesia are from the families Palaemonidae and Atyidae (Holthuis 1980; Chan 1998). The Macrobrachium is a genus of the Family Palaemonidae commonly found in Indonesia. This genus can be found in lotic and lentic waters, and their entire life cycle is in freshwater (Supriyadi 2012). Taufik (2011) stated that $M$. sintangense and $M$. lanchesteri are the most widely spread species of the genus Macrobrachium. M. lanchesteri is found in Thailand, Malaysia, Myanmar, Singapore, Sumatra, Borneo, and Java, and M. sintangense in Thailand, Sumatra, Java, and Borneo (Chong and Khoo 1988; Wowor et al. 2009). Supriyadi (2012) found 3 
species of the genus Macrobrachium in the upstream of Mount Salak River, while Desrita et al. (2018) found 6 species of freshwater shrimp in the upper Wampu watershed. According to Wowor et al. (2009) and Taufik (2011), freshwater shrimps have important roles in maintaining the balance of the ecological system in the waters and as food chain components. The presence of various species of freshwater shrimp in a river can be used as water quality indicator, and can improve the environmental quality of the river (Trijoko et al. 2015).

Table 1. Species of nekton caught in Batangtoru River and its tributaries, North Sumatra, Indonesia

\begin{tabular}{|c|c|c|c|c|}
\hline Family/species & Indonesian name & Local name & Common name & Locations \\
\hline \multicolumn{5}{|l|}{ Anguilidae } \\
\hline Anguilla bicolor & Sidat & Lumpe, & Shortfin Eel & $1,2,3,5,7,8,10,11,12,13,14,15,16,17$ \\
\hline Anguilla marmorata & Sidat & Dungdung & Giant mottled eel & $18,21,29,30$ \\
\hline \multicolumn{5}{|l|}{ Aplocheilidae } \\
\hline \multicolumn{5}{|l|}{ Bagridae } \\
\hline Hemibagrus caveatus & Baung & Baung Suat & Catfish & $1,2,3,4,5$ \\
\hline Leiocassis micropogon & Baung Kuning & Baung & Bumblebee catfish & $2,3,5,7,11,12,17$ \\
\hline Mystus nemurus & Baung & Baung & Yellow catfish & $\begin{array}{l}1,2,3,4,5,7,11,12,13,14,15,16,17,19 \\
20,21,22,24,25\end{array}$ \\
\hline Mystus nigriceps & Baung & Keting & Two spot catfish & $1,2,3,4,5,7,11,12,14$ \\
\hline Mystus gulio & Baung & Baung & Long whiskers catfish & 1 \\
\hline \multicolumn{5}{|l|}{ Balitoridae } \\
\hline Nemacheilus fasciatus & Uceng & Incor & Barred loach & $6,7,8,9,10,14,15,18,19,20,24,30$ \\
\hline Nemacheilus longipinnis & Uceng & Incor & Loach fish & 18,30 \\
\hline Homaloptera gymnogaster & Uceng & Incor & Lizard loach & $8,9,11,12,34$ \\
\hline \multicolumn{5}{|l|}{ Belontidaae } \\
\hline Trichogaster trichopterus & Sepat rawa & Capet & Spotted gourami & $1,2,3,4,25,29$ \\
\hline Trichogaster pectoralis & Sepat siam & Siam & Snakeskin gourami & $1,2,3,4$ \\
\hline \multicolumn{5}{|l|}{ Chandidae } \\
\hline Ambassis buruensis & Serinding & Kaca-kaca & Buru glass perchlet & 1 \\
\hline \multicolumn{5}{|l|}{ Channidae } \\
\hline Channa gacua & Gabus & Bakok & Dwarf snakehead & $7,11,12$ \\
\hline Channa lucius & Gabus & Bujuk & Splendid snakehead & $1,2,3,4$ \\
\hline Channa striata & Gabus & Gabus & Snakehead murrel & $\begin{array}{l}1,2,3,4,5,7,14,15,16,19,20,24,25,26 \\
27,28,29,30,33\end{array}$ \\
\hline \multicolumn{5}{|l|}{ Cichlidae } \\
\hline Oreochromis mossambicus & Mujaer & Jaer & Mozambique tilapia & $1,2,3,4,16,25,26,27,28,30$ \\
\hline Oreochromis niloticus & Nila & Nila & Nile tilapia & $1,2,3,4,7,14,16,25,26,27,28,30$ \\
\hline \multicolumn{5}{|l|}{ Clariidae } \\
\hline Clarias batrachus & Lele kampung & Tingkalang & Walking catfish & $\begin{array}{l}1,2,3,4,5,7,16,17,19,20,24,25,26,27, \\
28,29,30,33\end{array}$ \\
\hline Clarias gariepinus & Lele dumbo & Lele dumbo & Walking catfish & 30 \\
\hline Clarias teijsmanni & Lele & Limbat & Walking catfish & $1,2,3,4,5,6,7$ \\
\hline \multicolumn{5}{|l|}{ Cyprinidae } \\
\hline Cyprinus carpio & Mas & Mas & Common carp & $4,26,27,28,30$ \\
\hline Cyclocheilichthys apogon & Keperas & Sitengkal & Beardless barb & $1,2,3,4,5$ \\
\hline Cyclocheilichthys enoplos & Keperas & Sitengkal & Soldier river barb & $1,2,3,4,5$ \\
\hline Hampala macrolepidota & Sebarau & Hampala & Hampala barb & $\begin{array}{l}1,2,3,4,5,7,11,12,13,14,15,16,17,21 \\
22,23,25,26\end{array}$ \\
\hline Mystacoleucus marginatus & Cencen & Cencen & Burmese rainbow barb & $\begin{array}{l}1,2,3,4,5,7,11,12,13,14,16,17,24,25 \\
26\end{array}$ \\
\hline Osteochilus hasselti & Nilem & Paweh & Hard lipped barb & $\begin{array}{l}1,2,3,4,5,11,12,15,16,17,19,23,24 \\
25,26\end{array}$ \\
\hline Osteochilus kahajanensis & Nilem & Paita & Barb & $1,2,3,4,5,16,24,25$ \\
\hline Osteochilus kappenii & Neilem & Lampam & Barb & $1,2,3,4,5$ \\
\hline Osteochilus kelabau & Nilem & Lampam & Barb & $1,2,3,4,5$ \\
\hline Osteochilus microcephalus & Paitan & Nelan & Bonylip barb & $1,2,3,4,5,7,11,12,14$ \\
\hline Osteochilus melanopleura & Haro & Lampam & Barb & $1,2,3,4,5,7,11,12$ \\
\hline Puntius binotatus & Keperas & Pora-pora & Spotted barb & $\begin{array}{l}6,7,8,9,11,12,15,16,17,18,19,24,25 \\
26,29,30,33\end{array}$ \\
\hline Puntius brevis & Keperas & Pora-pora & Swamp barb & $\begin{array}{l}5,6,7,8,9,11,12,15,16,17,18,19,20 \\
21,24,25,26,27,28,29,30,31,32,33,34\end{array}$ \\
\hline Puntius lateristriga & Wader belang & Pora-pora & T-barb & $6,9,15,24,25$ \\
\hline
\end{tabular}




\begin{tabular}{|c|c|c|c|c|}
\hline Rasbora sumatrana & Seluang & Sulum & Sidestripe rasbora & $\begin{array}{l}2,6,7,9,10,11,12,13,14,15,16,17,18 \\
19,20,24,25,26,29,31,32,33\end{array}$ \\
\hline Rasbora spilotaenia & Seluang & Sulum & Rasbora & 30 \\
\hline Rasbora elegans & Seluang & Sulum & Elegant rasbora & $8,9,141,15,16,24,25$ \\
\hline Tor soro & Jurung & Ihan, mera & Mahseer & except 4 \\
\hline Tor tambra & Jurung & Ihan, mera & Mahseer & except 4,6 , and 9 \\
\hline Helostomatidae & & & & \\
\hline $\begin{array}{l}\text { Helostoma temminckii } \\
\text { Gobiidae }\end{array}$ & Tambakan & Alu & Kissing gourami & $1,2,3$ \\
\hline Boleophtalmus boddarti & Belodok & Tembakul & The mudskipper & 1 \\
\hline $\begin{array}{l}\text { Periopthalmonodon } \\
\text { schlosseri }\end{array}$ & Belodok & Tembakul & Giant mudskipper & 1 \\
\hline Loricariidae & & & & \\
\hline $\begin{array}{l}\text { Hypostomus plecostomus } \\
\text { Lutjaniidae }\end{array}$ & Ikan sapu-sapu & Ikan terbang & The suckermouth catfish & $1,2,3,5$ \\
\hline $\begin{array}{l}\text { Lutjanus johnii } \\
\text { Mastacembelidae }\end{array}$ & Kakap & Kakap & John's snapper & 1 \\
\hline $\begin{array}{l}\text { Macrognathus maculatus } \\
\text { Megalopidae }\end{array}$ & Tilan & Mirik & Buff-backed spiny eel & $11,12,15$ \\
\hline $\begin{array}{l}\text { Megalops cypronoides } \\
\text { Mugiliidae }\end{array}$ & Bulan-bulan & Bulan-bulan & The indo-pacific tarpon & 1 \\
\hline $\begin{array}{l}\text { Valamugil engeli } \\
\text { Poeciliidae }\end{array}$ & Belanak & Belanak & Kanda mullet & 1 \\
\hline Poecilia reticulata & Guppy & Buntat & Guppies & $7,24,25,27,28,29,30,32,33$ \\
\hline $\begin{array}{l}\text { Xiphophorus helleri } \\
\text { Pristolepididae }\end{array}$ & Platy pedang & Guppi & Green swordtail & $29,30,32,33$ \\
\hline $\begin{array}{l}\text { Pristolepis grooti } \\
\text { Scatophagidae }\end{array}$ & Sepatung & Kupar & Indonesian leaffish & $1,2,3,4$ \\
\hline $\begin{array}{l}\text { Scatophagus argus } \\
\text { Siluridae }\end{array}$ & Ketang & & Spotted butterfish & 1 \\
\hline $\begin{array}{l}\text { Ompok bimaculatus } \\
\text { Sisoridae }\end{array}$ & Ompok & Lais & Indian butter-catfish & $1,2,3$ \\
\hline Glyptothorax major & Lele gunung & Sating & Sucking catfish & $\begin{array}{l}7,9,10,11,12,14,15,16,17,18,19,31 \\
32,33,34\end{array}$ \\
\hline Glyptothorax platypogon & Lele gunung & Sating & Sucking catfish & $\begin{array}{l}7,8,9,10,11,12,14,15,16,17,31,32,33 \text {, } \\
34\end{array}$ \\
\hline Synbranchidae & & & & \\
\hline $\begin{array}{l}\text { Monopterus albus } \\
\text { Others }\end{array}$ & Belut & Bolut & Asian swamp eel & $11,12,19,20,24,25$ \\
\hline $\begin{array}{l}\text { Crustacea } \\
\text { Palaemonidae }\end{array}$ & l & & & \\
\hline Macrobrachium equidens & & & Rough river prawn & $1,2,3$ \\
\hline Macrobrachium lar & & & Monkey river prawn & $1,2,3$ \\
\hline Macrobrachium lanchesteri. & Udang & Udang & Glass shrimp & $\begin{array}{l}4,6,7,9,11,12,13,14,15,16,17,18,19 \\
20,21,23,24,25,26,27,28,29,30,31,32 \\
33\end{array}$ \\
\hline Macrobrachium nipponense & & & & $1,2,3$ \\
\hline Macrobrachium pilimanu & & & & $1,2,3$ \\
\hline Macrobrachium sintangense & Udang & Udang & Freshwater shrimp & $\begin{array}{l}4,6,7,9,11,12,13,14,15,16,17,18,19, \\
20,21,23,24,25,26,27,28,29,30,31,32, \\
33\end{array}$ \\
\hline $\begin{array}{l}\text { Parathelphusidae } \\
\text { Parathelphusa convexa } \\
\text { Parastacidae }\end{array}$ & Kepiting tawar & Yuyu & Panther crab & $9,11,12$ \\
\hline $\begin{array}{l}\text { Cherax quadricarinatus } \\
\text { Portunidae }\end{array}$ & Lobster air tawar & Lobster & Redclaw crayfish & $11,12,25,26$ \\
\hline Scylla serrata & Kepiting bakau & Kepiting & Mud crab & 1 \\
\hline $\begin{array}{l}\text { Scylla oceanica } \\
\text { Reptil }\end{array}$ & Kepiting bakau & Kepiting & Mud crab & 1 \\
\hline Amyda cartilaginea & Bulus & Labi-labi & Asiatic shoftshell turtle & 15 \\
\hline
\end{tabular}




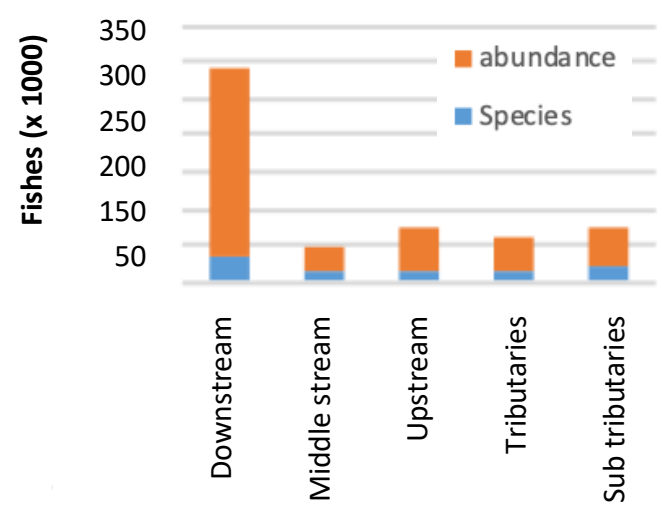

Locations

Figure 2. The number of species and abundance of fish at Batangtoru River and its tributaries

It is interesting that in the Batangtoru River a freshwater turtle (A. cartilaginea) was found, at station 15 (Dolok Nauli). Although this species is not categorized as a rare species, it is rarely found in Indonesia, especially in North Sumatra. However, this species was also found in the Wampu watershed by the authors in 2017 (unpublished).

Eels are found along the Batangtoru River, from the estuary (station 1) to upstream in Sidagal (station 31) including the main tributaries, such as Aek Puli (stations 11 and 12) and Aek Parsariran (stations 6 and 7). Information obtained from the locals, however, indicated that eels do not swim through Aek Gideon (station 22) to Sipultak Dolok (station 29) and Banua Luhu (station 30), including Onan Rungu (station 33) and Lobu Siregar (station 34). In this case, 2 species of eel were found, namely $A$. marmorata (less commonly found) and A. bicolor (more commonly found).

\section{Spatial distribution of nekton}

Spatially, the highest species abundance was found in the downstream; at least 25-45 nekton species were found. The least abundance were found in the upstream with 5-18 species of nekton. In the middle stream, 5-19 species were found, and it was higher than in the upstream. In the tributary, 7-27 species of nekton were found, but still lower than in the sub tributaries where 8-27 species were found. The high species abundance in the downstream was also followed by the number of fish which was 258 individuals, where in the middle stream only 34 are found and 64 in the upstream. Meanwhile, in tributaries 48 species were found, fewer than that in sub-tributaries, which reached 55. The high number of fish species in the downstream is due to the higher variety of available niches, which are rivers and swamps. The estuary is a meeting area of two types of fish: freshwater fish and seawater fish, such as snapper and mullet. The downstream was dominated more by catfish, barb, snakehead, and eel.

Fish abundance was low in the upstream because this habitat is narrow and has few niches, limited mainly by currents. Both locations are rugged and steep, so they form deep areas, strongly dominated by shallow and, low currents. In other locations (middle stream), although there is a strong current, some of the banks are gentle slopes, so shallow areas and low currents are still found. Based on Muhtadi et al. (2017) and Desrita et al. (2018), river waters with strong and deep currents have lower fish diversity than low and shallow rivers. Furthermore, Desrita et al. (2018; 2019) found large Tor (usually> $12 \mathrm{~cm}$ ) in the river with strong current $(2.5 \mathrm{~m} \mathrm{/} \mathrm{s})$, and small-sized Tor in medium and low currents. Kottelat et al. (1993) mention that Tor with torpedo body shapes prefer strong currents. Other species of fish that tend to live in strong currents are Leiocassis micropogon and Mystacoleucus marginatus. L. micropogon can even withstand strong currents among large rocks. $M$. marginatus tends to be in heavy flow with small rock or gravel substrate. Puntius, Rasbora, Macrognathus maculatus, and Macrobrachium are types of fish that prefer low currents in river sections with gravel or sand substrates. The fish are commonly found in the channel (very small rivers that flow into the main river).

Many Cyclocheilichthys and Poecilia reticulata were found in the upstream of Batangtoru River in Siborongborong and Sipahutar with low currents, sandy substrates and shallow waters. Even at these three locations, many guppies including Xiphophorus helleri were found: they might have entered the waters accidentally. As a note, $X$. Helleri is not native fish in the Batangtoru River. Nevertheless, in all three locations, Tor and glass shrimp were still found. However, the locals informed that there is a lot of fish that are "separated" from the community's ponds living there, namely Clarias, Tilapia, and carp. In another upstream area of Sidagal Siatas Barita Village (31), there are rocks /pebbles, and the waters have mediumstrong current and no $P$. reticulata was found. The fish community was dominated by Tor and Panchax panchax (the observation station near the ricefield). During the samplings, only Tor, Glyptothorax, and Panchax were found due to the deep water and heavy currents. According to the locals in Sidagal Village, large Tor is usually caught before the rice harvest season, which is approximately the dry season, and at that location a large eel (dungdung) was found, indicating the fish migrated from the ocean (Indian Ocean) to the village of Sidagal (31).

In Batangtoru sub-tributaries, not only Tor and Macrobrachium but also Osteochilus, Hampala macrolepidota, Puntius lateristriga, catfish, and incor were found. Osteochilus and Hampala were mostly found in Tarutung (stations 24 and 25) which flow from the Aek Gideon River and Aek Puli (stations 11-13) heading to Batangtoru (Simangumban), including from Dolok Nauli River (stations 15 and 16), while incor was found in clear and rocky waters (stations 6,7,18,19,20,34).

The different spatial distribution of nekton in the Batangtoru River and its tributaries shows that each observation station provides different niches, so the species composition of fish community is different. Some researchers mention that spatial distribution and abundance of species are related to the differences in habitat and the presence of microhabitat, substrate composition and water depth (Gordon et al. 2004), the diversion of water masses for irrigation/hydropower and the damage to vegetation 
around rivers (Adams et al. 2004; Beugly and Pyron 2010; Simanjuntak 2012a). Specifically for Tor, Wahyuningsih et al. (2016) found genetic variation and morphology of Tor along with differences in their habitat.

\section{Nekton diversity}

The highest diversity index $\left(\mathrm{H}^{\prime}\right)$ of nekton in the Batangtoru River and its tributaries was found in the downstream and lowest in the upstream (Figure 3). As mentioned in the previous description, station $\mathrm{AB} 5$ is a steep and fast-flowing area, so the fish are able to adapt to heavy currents, one of which is mahseer. This is related to the previous discussion that there are fewer microhabitats in the upstream than in other stations, especially in the downstream with more heterogeneous microhabitats. Thus, there is an opportunity for fish that do not favor the strong currents to live at low currents, which is not available in the upstream locations. Therefore, upstream was dominated more by Tor and Cyclocheilichthys.

Compared to the diversity index $\left(\mathrm{H}^{\prime}\right)$ of nekton in other rivers in Indonesia, the fish diversity in Batangtoru River and its tributaries was high. Djumanto and Probosunu (2011), found that fish diversity index $\left(\mathrm{H}^{\prime}\right)$ in the upstream Opak River, Yogyakarta was about 1.44-1.9. Haryono (2004), obtained the diversity index $\left(\mathrm{H}^{\prime}\right)$ of fish in the rivers around the Muller Mountains, Central Kalimantan of 0.80 to 2.17. Desrita et al. (2018) also found a high diversity index $\left(\mathrm{H}^{\prime}\right)$ of fish in the upstream Wampu watershed, i.e., 1.83-2.90. The high diversity of fish in the Batangtoru River and its tributaries compared to other watersheds, especially the Wampu watershed (LangkatNorth Sumatra), is caused by the heterogeneity of microhabitats in Batangtoru River and its tributaries due to the presence of swamps. The highest evenness index in Batangtoru River and its tributaries was found in the middle stream and sub tributaries and the lowest in the downstream. Generally, the evenness index in these study sites was considered high $(>0.75)$, indicating that no species was truly dominant in the Batangtoru River and its tributaries, as shown by its low dominance index $(<0.5)$. The dominance index range was from 0.10 to 0.22 with the highest value found in the upstream. In the upstream area, Tor and Puntius were more commonly found. Both species are from the Family Cyprinidae that live in the deep, moderate to heavy flow, and clear water (Simanjuntak 2012a; Desrita et al. 2018). This is result is different from Simanjuntak (2012a) in Asahan River, in which the dominance value was around 0.21-1.0. The dominance index value approaches 1 if the community is dominated by certain species and it approaches 0 , if no species dominates the community (Odum and Barrett 2009).

This evenness index was slightly different from the species abundance, the lowest species abundance was found in upstream but the lowest evenness value in downstream. This shows that diversity does not only depend on abundance but also influenced by the proportion of each species in the community. This is the same as Odum and Barrett (2009) statement: although many species are found, it does not mean that the diversity index is high. The proportion of each species affects the diversity index.

\section{Discussion}

In general, the species of nekton found in Batangtoru River and its tributaries are native fish that have high economic value, such as Tor and eel, including the newly discovered species, $H$. caveatus. There were 6 invasive species found in study sites, i.e., $C$. carpio, $O$. mossambicus, O. niloticus, X. helleri, H. Plecostomus, and $T$. pectoralis. According to fishbase.org (2019) and Sugianti et al. (2014), common carp and tilapia are invasive species which can have negative impacts for on biodiversity, (Sugianti et al. 2014). Furthermore, Sugianti et al. (2014) state that invasive fish is a threat that can endanger the preservation of native species. The influence of invasive species on native species varies: they can be competitors, predators, pathogens, and parasites. The species categorized as an invasive species in Batangtoru River and its tributaries is freshwater Lobster $(C$. quadricarinatus).

In this study, no endemic aquatic organism was found. However, species in the "vulnerable" category of Appendix II (CITES) namely A. cartilaginea was found. Apparently, goldfish in their natural habitat (Central Asia) are included in the Vulnerable category, while in Indonesia (including in Batangtoru watershed) their presence is quite abundant as cultured fish and fish that are "released" into the waters. Species in threatened category are $L$. micropogon, $M$. nigriceps, N. Fasciatus, N. Longipinnis, O. kahajanensis, P. reticulata, $R$. sumatrana, $R$. spilotaenia and including Tor soro. Other species are included in the near threatened and least concern categories. Meanwhile, based on animal protection regulations in Indonesia, 36 species in Batangtoru River and its tributaries are not included in the protected animals category. Meanwhile, in the local community, jurung are seasonally protected in Lubuk Larangan (literally means: prohibited rver). Lubuk Larangan is often found in South Tapanuli and also in North Tapanuli (Pahae and Simangumban areas). Lubuk larangan is local wisdom for protecting jurung and automatically protecting other fish. As the implementation of Lubuk Larangan, people are allowed to catch the fish that live in "protected" (prohibited) river until the specified time, usually opened at the Eid or the Moslem holiday after the fasting month of Ramadan (in South Tapanuli) and New Year (in North Tapanuli).

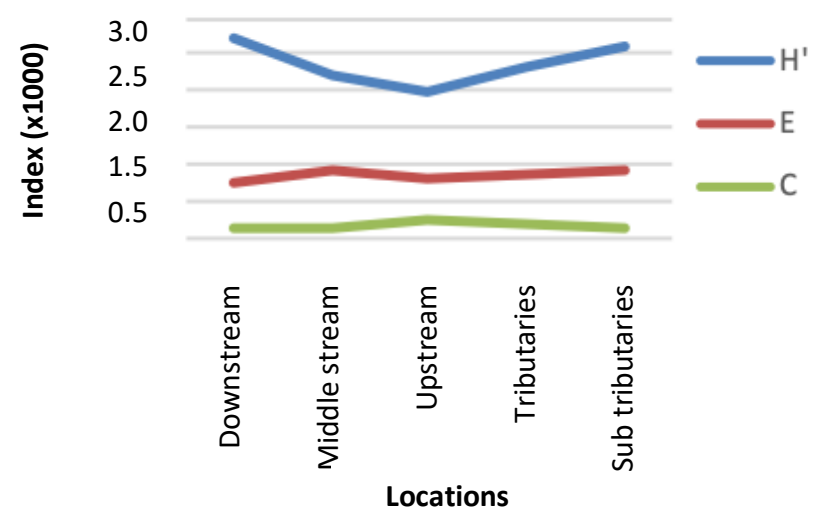

Figure 3. Diversity, evenness and dominance indexes in Batangtoru River and its tributaries, North Sumatra, Indonesia 


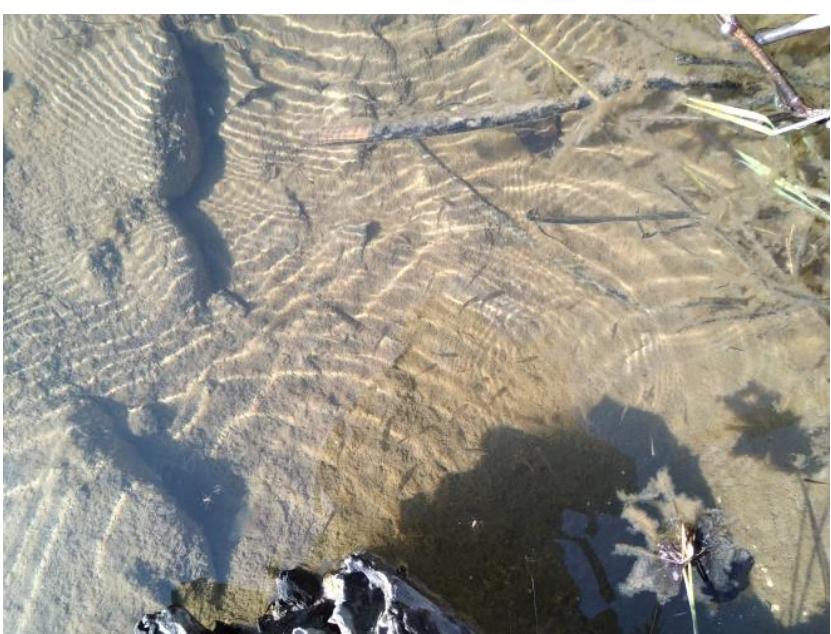

Figure 4. The condition of rocks on the bank of the river spawning place for larval or juvenile of Tor (location on the River Botek Aek, station 34)

This study found migratory fish such as eel (A. bicolor and A. marmorata). These eels migrate from upstream to downstream (sea) to spawn as they are anadromous. In other words, eels migrate longitudinally along the main river or several tributaries that are connected to the main river (Batangtoru River). This fish is an economically important fish that is able to migrate to the middle of the sea. Based on the information and observations in the field, around the central Batangtoru (Tarutung, Pahae Julu, Pahae Jae, and Sipirok) and the downstream (Raniate), the eels were still found in Batangtoru River. This shows consistent condition from upstream (Sidagal, station 31), Hutapea (station 22), to Batu Mundom (station 1) including several other tributaries (Parsariran, station 7), Marancar (stations 8,10 ), Sipirok (stations 11, 12), Dolok Nauli (station 15), so eels were still found at those locations. While at Sipoholon and Siborong-borong (stations 24-30 and 33-34), based on information from the locals, no eel has ever found. This shows that eels migrate upstream in Batangtoru River to Sidagal and do not cross the Aek Gideon River to the Siborong-borong area. Based on the study and information from the locals, the main habitat of the eels is in Sidagal Village (31) and Hutapea Village, the tributaries of Parsariran (station 6), and Aek Puli (stations 11-13) and other similar water types that have many "riverbeds" that serve as the eel shelter. These locations are very suitable as eel's habitat, which is a river segment with many deep riverbeds among rocks and on the bank of a fast-flowing river. According to Vamellia (2014) and Hakim (2015) eel grows well in the upstream of swift waters that have $>1 \mathrm{~m}$ riverbed to stay and hide.

Tor migrates to the upstream for spawning. Tor spawns in the gaps of the rocks (gravel) in the upstream area in shallow river. Even though the fish spawn in deep downstream, the eggs are hatched in shallow river (Haryono and Subagja 2008). Thus, the fish migrate longitudinally from downstream to upstream, but not up to sea.
Based on field studies, it is suspected that Tor is located upstream. According to Haryono and Subagja, (2008) and Desrita et al. (2018), large Tor lives in deep part of swift waters, while small fish live in shallower waters with lower currents, and larvae and juvenile are found in shallower waters in rivers (Figure 4).

Meanwhile, several nekton species migrate laterally from the main river to the nearest tributary (swamp flood) for spawning. Laterally migratory fish are those from the families Channidae and Claridae, and the genus Osteochilus. For example, Osteochilus, found in Tarutung (stations 22-23) will make lateral migration from the main river (Aek Gideon) to a small river at stations 24-25. Based on the results of studies on reproduction, some Osteochilus were found ready to spawn (Gonad Maturity Stage IV). Omar (2010) explains that Osteochilus are partially spawners that spawn in the rainy season, starting from the beginning of the rainy season until the end of the rainy season. Almost all tropical freshwater fish spawn in the rainy season (Ballesteros et al. 2009), and only a few spawn in the dry season or throughout the year (AlkinsKoo 2000; Pusey et al. 2002; Torres-Mejia et al. 2008). Some species that do not migrate (in the context of spawning) are those of the families Balitoridae, Mastacembelidae, Poeciliidae, Sisoridae, and also shrimp (Palaemonidae). Those species spawn in the habitat where they live.

\section{ACKNOWLEDGEMENTS}

This research was funded by the Universitas Sumatera Utara through the TALENTA research scheme in 2019. We would like to thank Ahyar Pulungan, Ali Muktar Rangkuti, and Armansyah Rangkuti for their assistance during this research in the field.

\section{REFERENCES}

Adams SB, Warren ML, Haag JWR. 2004. Spatial and temporal patterns in fish assemblages of upper coastal plain streams, Mississippi, USA. Hydrobiol 528: 45-61

Alkins-Koo M. 2000. Reproductive timing of fishes in a tropical intermittent stream. Environ Biol Fish 57 (1): 49-66.

Ballesteros TM, Torres-Mejia M, Ramírez-Pinilla MP. 2009. How does diet influence the reproductive seasonality of tropical freshwater fish? A case study of characin in a tropical mountain river. Neotropical Ichthyol 7 (4): 693-700.

Beugly J, Pyron M. 2010. Temporal and spatial variation in the long-term functional organization of fish assemblages in a large river. Hydrobiol 654: 215-226.

Chan TY. 1998. Shrimps and prawns, Lobster. In: Carpenter KE, Niem VH (eds). FAO Identification Guide for Fisheries Purpose, The Living Marine Resources of the Western Central Pacific. FAO, Rome.

Chong SSC, Khoo HW. 1988. The identity of Macrobrachium lanchesteri (De Man,1911) (Decapoda, Palaemonidae) from Peninsular Malaysia and Singapore, and a description of its first zoea. Crustaceana 54: 196-206.

CITES UNEP-WCMC. 2017. The Checklist of CITES Species Website. Appendices I, II and III valid from 04 April 2017. CITES Secretariat, Geneva, Switzerland. Compiled by UNEP-WCMC, Cambridge, UK. https://www.cites.org/eng/app/appendices.php [01/08/2017] 
Dekar M, Sarong MA, Batubara AS, Muchlisin ZA. 2018. Ichthyofauna of Aceh River, Aceh Province, Indonesia. IOP Conf Ser Earth Environ Sci 216: 012024. DOI: 10.1088/1755-1315/216/1/012024.

Desrita A, Muhtadi A, Tamba IS, Ariyant J, Sibagariang RD. 2018 Community structure of nekton in the upstream of Batangtoru Watershed, North Sumatra, Indonesia. Biodiversitas 19 (4): 13661374.

Desrita, Tamba IS, Muhtadi A, Ariyanti J, Leidonald R. 2019. Diversity and habitat condition of Tor Fish (Tor spp.) in the upstream of Wampu Waters, North Sumatra, Indonesia. IOP Conf Ser Earth Environ Sci 260: 012102. DOI: 10.1088/1755-1315/260/1/012102.

Djumanto, Probosunu N. 2011. Fish resource biodiversity upstream of the Opak River. Jurnal Iktiologi Indonesia 1 (1):1-10. [Indonesian]

Gordon ND, Thomas A, McMahon, Finlayson BL. 2004. Stream Hydrology: An Introduction for Ecologists 2nd ed. John Wiley and Sons Ltd, Chichester, England.

Hakim AA, Kamal MM, Butet NA, Affandi R. 2015. Species composition of freshwater Eels (Anguilla spp.) in eight rivers flowing to Palabuhanratu Bay, Sukabumi, Indonesia. Jurnal Ilmu dan Teknologi Kelautan Tropis 7 (2): 573-585. [Indonesian]

Hakim AA. 2015. Determination of Fisheries Refugia Area of Freshwater Eels (Anguilla spp.) from Some Rivers that Flows to Palabuhanratu Bay, Sukabumi, Jawa Barat. [Thesis]. Postgraduate Program, Bogor Agricultural University, Bogor. [Indonesian]

Hamidah A. 2004. Diversity of fish species in the Enim River, Muara Enim Regency, South Sumatra Province. Jurnal Iktiologi Indonesia 4: 51-55. [Indonesian]

Haryono, Subagja J. 2008. The population and habitat of Tambra fish, Tor tambroides (Bleeker, 1854) in Muller Mountain waters Central Kalimantan. Biodiversitas 9 (4): 306-309.

Haryono. 2004. The Cyprinidae tribe fish community in the waters around Bukit Batikap in the Muller Mountains region of Central Kalimantan. Jurnal Iktiologi Indonesia 4 (2): 79-84. [Indonesian]

Hee Ng H, Wirjoatmodjo S, Hadiaty RK. 2001. Hemibagrus caveatus, A New Species of Bagrid Catfish (Teleostei: Siluriformes) From Northern Sumatra. Raffles Bull Zool 49: 359-361.

Holthuis LB. 1980. FAO species catalogue Volume 1: Shrimps and Prawn of the World. FAO, Rome.

https:// fishbase.org/

https://www.iucnredlist.org/

Irhami S, Fithri A, Batubara AS, Muchlisin ZA. 2018. Fish fauna of Meureubo River, Aceh Barat District, Indonesia. IOP Conf Ser Earth Environ Sci 216: 012023. DOI: 10.1088/1755-1315/216/1/012023.

Kottelat M, Whitten AJ, Kartikasari SN, Wirjoatmodjo S. 1993. Freshwater Fishes of Western Indonesia and Sulawesi. Periplus Editions Limited, Jakarta.

Krebs CJ. 1989. Ecological Methodology. University of British Columbia, Harper Collins Publisher, New York.

Margasasmita S. 2002. Endangered Sumatra Endemic Freshwater Fish. Jurnal Iktiologi Indonesia 2 (2): 5-10. [Indonesian]

Muchlisin ZA, Siti-Azizah MN. 2009. Diversity and distribution of freshwaters fish in Aceh waters Northern Sumatera Indonesia. Intl J Zool Res 5 (2): 62-79.

Muhtadi A, Cordova MR, Yonvitner. 2014. Aquatic Ecology: A Practical Guide. IPB Press, Bogor.

Muhtadi A, Dhuha OR, Desrita, Siregar T, Muammar. 2017. Habitat conditions and diversity of necton in catchman area of Batangtoru River, Langkat Regency, North Sumatra Province. Depik 6: 90-99.

Nguyen TTT, de Silva SS. 2006. Freshwater finfish biodiversity and conservation: An Asian perspective. Biodivers Conserv 15: 3543 3568 .

Odum EP, Barrett GW. 2009. Fundamentals of Ecology. 5th ed. Cengage Learning, Belmont, CA
Omar SBA. 2010. Reproductive biology of bonylip barb, Osteochilus vittatus (Valenciennes, 1842) in Sidenreng Lake, South Sulawesi. Jurnal Iktiologi Indonesia 10 (2): 111-122. [Indonesian]

Pranata ND, Purnama AA, Yolanda R, Karno R. 2016. Iktiofauna Sungai Sangkir Kabupaten Rokan Hulu Provinsi Riau. Depik 5: 100-106. [Indonesian]

PT. North Sumatra Hydro Energy. 2016. Addendum Environmental Impact Assessment Plan for Development of Water Power Plant Of $500 \mathrm{Mw}$ to $510 \mathrm{Mw}$ (4 X 127.5 Mw) and Quarry Location Change in Tapanuli District, South Sumatera Utara Province, Indonesia.

Pusey BJ, Arthington AH, Close PG, Bird JR. 2002. Larval fishes in rainforest streams: Recruitment and microhabitat use. Proc R Soc Qld 110: 27-46.

Simanjuntak CPH. 2012a. Diversity and Distribution of the SpasioTemporal Iktiofauna River Asahan Upstream and its Tributary. Prosiding Seminar Nasional Ikan VII. Makassar, 12 Juni 2012. [Indonesian]

Simanjuntak CPH. 2012b. The diversity and structure of schools of fish in the tributary streams of Sopokomil, Dairi, North Sumatra. Jurnal Iktiologi Indonesia 12 (2): 155-172. [Indonesian]

Siregar S, Putra RM, Sukendi. 1993. Fish fauna in the waters of the Bukit Tigapuluh Siberida sector, Sumatra. Rain Forest and Resource Management. Proceedings of the NORINDA. Jakarta, 23-25 Mei 1993

Sugianti B, Enjang HH, Nuah J, Yeni A. 2014. List of Pisces that Potentially are Invasive Foreign Species in Indonesia. Cetakan ke-2 (edisi revisi). Kementerian Kelautan Perikanan, Jakarta. [Indonesian]

Taufik. 2011. Diversity of Freshwater Shrimp in Kerinci Lake, Jambi Province. [Thesis]. Faculty of Mathematics and Natural Science, Bogor Agricultural University, Bogor. [Indonesian]

Torres-Mejia M, Ramírez-Pinilla MP. 2008. Dry-season breeding of a characin in a tropical mountain river. Copeia 1: 99-104.

Trijoko NS, Handayani N, Widianawati A, Eprilurahman R. 2015. Morphological and molecular characteristics of Macrobrachium spp. from the Opak River in the Special Region of Yogyakarta. Biogenesis 3 (1): 1-10. [Indonesian]

Vamellia A. 2014. Water Quality in the Rivers that End in Palabuhan Ratu Bay, West Java as Habitat for Eels (Anguilla spp.). [Thesis]. Department of Aquatic Resource Management, Faculty of Fisheries and Marine Science, Bogor Agricultural University, Bogor. [Indonesian]

Wahyuningsih H, Hannum S, Muhtadi A. 2016. Distribution, Morphometric and Genetic Diversity and Enlargement of Tor Genus Fish in North Sumatra. [Final report]. Fundamental Research Funded by the Directorate of Research and Community Service Directorate General of Strengthening Research and Development at the Ministry of Research, Technology and Higher Education, Research Institute, University of North Sumatra, Medan. [Indonesian]

Welch PS. 1952. Limnology. 2nd ed. Mc Graw-Hill Book Company Inc, New York.

Wowor D, Cai Y, Ng PKL. 2004. Crustacea: Decapoda, Caridea. In: Yule $\mathrm{CM}$, Sen YH (eds). Freshwater Invertebrata of the Malaysian Region. Akademi Sains Malaysia, Kuala Lumpur.

Wowor D, Muthu V, Meier R, Balke M, Cai Y, Ng PKL. 2009. Evolution of life-history traits in Asian freshwater prawns of Genus Macrobrachium (Crustacea: Decapoda: Palaemonidae) based on multilocus molecular phylogenetic analysis. Mol Phylogenet Evol 52: 340-350.

Wowor D. 2010. Study of Aquatic Biota and Herpetofauna in the Ciliwung and Cisadane Watersheds: Study of Biodiversity Loss. [Final report]. Researchers and Engineers Incentive Program 2010, Indonesian Institue of Sciences, Cibinong, bogor. [Indonesian]

Zakaria-Ismail M. 1994. Zoogeography and biodiversity of the freshwater fishes of Southeast Asia. Hydrobiology 285: 41-48. 